\title{
Firms' Financial Choices and Thin Capitalization Rules under Corporate Tax Competition
}

\author{
ANDREAS HAUFLER \\ MARCO RUNKEL
}

CESIFO WORKING PAPER No. 2429

CATEGORY 1: PUBliC FinANCE

OCTOBER 2008

Presented At CESifo Venice Summer Institute 2008, Workshop ON

'TAXATION OF MULTINATIONAL FIRMS'

\footnotetext{
An electronic version of the paper may be downloaded

- from the SSRN website: Www.SSRN.com

- from the RePEc website: Www.RePEc.org

- from the CESifo website: www.CESifo-group.org/wp
} 


\title{
Firms' Financial Choices and Thin Capitalization Rules under Corporate Tax Competition
}

\begin{abstract}
Thin capitalization rules have become an important element in the corporate tax systems of developed countries. This paper sets up a model where national and multinational firms choose tax-efficient financial structures and countries compete for multinational firms through statutory tax rates and thin capitalization rules that limit the tax-deductibility of internal debt flows. In a symmetric tax competition equilibrium each country chooses inefficiently low tax rates and inefficiently lax thin capitalization rules. We show that a coordinated tightening of thin capitalization rules benefits both countries, even though it intensifies competition via tax rates. When countries differ in size, the smaller country not only chooses the lower tax rate but also the more lenient thin capitalization rule.
\end{abstract}

JEL Code: H73, H25, F23.

Keywords: thin capitalization, capital structure, tax competition.

\author{
Andreas Haufler \\ University of Munich \\ Seminar for Economic Policy \\ Akademiestrasse 1/II \\ 80799 Munich \\ Germany \\ Andreas.Haufler@lrz.uni-muenchen.de
}

\author{
Marco Runkel \\ University of Magdeburg \\ Chair of Public Finance \\ P.O. Box 4120 \\ 39016 Magdeburg \\ Germany \\ Marco.Runkel@ovgu.de
}

September 2008

Paper presented at the European Tax Policy Forum in London and at the CESifo Workshop "Taxation of Multinational Firms" in Venice. We thank Sam Bucovetsky, Thiess Buettner, Mihir Desai, Michael Devereux, Ben Lockwood, Will Morris, Rainer Niemann, Michael Overesch, Dirk Schindler and Georg Wamser for helpful comments and discussions. The authors gratefully acknowledge financial support from the European Tax Policy Forum and from the German Research Foundation (Grants HA 3195/7-1 and RU 1466/1-1). 


\section{Introduction}

Existing corporate tax systems permit the deduction of interest payments from the corporate tax base, whereas the equity returns to investors are not tax-deductible. This asymmetric treatment of alternative means of financing investment offers firms a fundamental incentive to increase their reliance on debt finance. For multinational companies this incentive is further strengthened by the possibility to use internal debt as a means to shift profits from high-tax to low-tax countries. Recent empirical research provides conclusive evidence that international tax differentials affect multinationals' financial structure in a way that is consistent with overall tax minimization. ${ }^{1}$ Moreover, while profit shifting within multinational firms can occur through a variety of channels, there are clear empirical indications that the use of financial policies plays an important role in this process (Grubert, 2003; Mintz, 2004). For this reason, international debt shifting is suspected to be a core factor behind empirical findings that multinational firms seem to pay substantially lower taxes, as a share of pre-tax profits, as compared to nationally operating firms. ${ }^{2}$

In response to these developments, many countries have introduced thin capitalization rules, which limit the amount of interest payments to related entities that is deductible from the corporate tax base. As of today, the majority of OECD countries includes such constraints in their corporate tax codes, and several countries have introduced them during the last decade. ${ }^{3}$ As an example, Germany has tightened its existing thin capitalization rules in the corporate tax reform of 2008 by introducing a strict limitation for the tax-deductibility of interest payments equal to $30 \%$ of the firm's pre-

\footnotetext{
${ }^{1}$ Desai et al. (2004) show for U.S.-based multinationals that a $10 \%$ higher tax rate in the host country of a foreign affiliate raises the debt-to-asset ratio of this affiliate by about 3-4\%. Mintz and Weichenrieder (2005) and Buettner et al. (2006) obtain quantitatively similar results for German multinationals. Huizinga et al. (2008) provide more general evidence that the capital structure of European multinationals is adapted in a tax-minimizing way to international differences in corporate tax systems and corporate tax rates.

${ }^{2}$ For Europe, Egger et al. (2007) have estimated, using econometric matching techniques, that the tax burden of an otherwise similar manufacturing plant is reduced by more than $50 \%$ when the parent firm is foreign-owned, rather than domestically-owned. Hines (2007) finds related evidence that the effective tax payments of U.S. multinationals in their respective host countries have fallen more rapidly than the statutory tax rates in these countries.

${ }^{3}$ Descriptions of existing thin capitalization rules are given by Gouthière (2005) for most OECD countries, and by Dourado and de la Feria (2008) for the EU member states.
} 
tax earnings. This new set of thin capitalization rules is explicitly targeted at the tax planning strategies of multinational enterprises.

On the other hand, the move to stricter thin capitalization rules is not universal. The United States, for example, which was one of the first countries to introduce an earnings' stripping rule in 1989, has introduced changes to its tax code in 1997 that facilitated the use of internal debt as a tax savings instrument for multinational firms. ${ }^{4}$ Ireland and, more recently, Spain have even abolished thin capitalization restrictions for loans from EU-based companies completely, in response to a 2002 ruling by the European Court of Justice that thin capitalization rules must be set up in a non-discriminatory way. In the case of Ireland, it is furthermore noteworthy that the relaxation of thin capitalization rules directly followed the forced termination of Ireland's split corporate tax rate, which had long been used as an instrument to provide preferential tax treatment to multinationals. This suggests that at least some countries might strategically use thin capitalization rules as a means to grant targeted tax relief to multinational firms.

These recent developments have also led to an increasing awareness in the European Union of the potential inefficiencies that result from a decentralized setting of thin capitalization rules. In a communication, the European Commission (2007) has announced its willingness to take coordinated actions against 'wholly artificial arrangements' used to shift profits between establishments, and explicitly includes thin capitalization rules as a possible countermeasure at the EU level. A more detailed discussion at the EU level has taken place in conjunction with the proposal to introduce a Common Consolidated Corporate Tax Base (CCCTB). A working group preparing this proposal has evaluated various alternatives to limit the deductibility of interest payments within multinational groups (European Commission, 2008). While no specific thin capitalization rule has been proposed yet it is generally expected that the directive proposal to introduce a CCCTB, announced by the Commission for the fall of 2008, will include thin capitalization provisions (see, e.g., Fuest, 2008).

Despite the policy relevance of the subject, and in contrast to a growing body of

\footnotetext{
${ }^{4}$ The main element among these tax changes were so-called 'check-the-box' provisions which introduced hybrid entities that are considered as corporations by one country, but as unincorporated branches by another. These rules can be used by U.S. multinationals to circumvent existing rules for controlled foreign corporations (CFC rules), which disallow the deferral of passive business income, including interest payments, for the affiliates of U.S. corporations. See OECD (2007), ch. 5.
} 
empirical research (see below), we are unaware of a theoretical analysis that explicitly focuses on the positive and normative aspects of the choice of thin capitalization rules by countries engaged in international tax competition. This is what we aim to do in the present paper.

We consider a model with two potentially asymmetric countries and national as well as multinational firms. Tax competition for internationally operating firms occurs through statutory tax rates and thin capitalization rules that limit the tax-deductibility of internal debt flows within the multinational enterprise. Both multinational and national firms can also respond to a higher domestic tax rate by increasing the level of external debt finance. We first consider the case of symmetric countries and show that tax competition leads to inefficiently low tax rates and inefficiently lax thin capitalization rules, relative to the Pareto efficient solution. This serves as a convenient benchmark from which our main results can be derived.

The first central result of our analysis is that, starting from the symmetric tax competition equilibrium, a coordinated tightening of thin capitalization rules is mutually welfare-increasing, even if countries are free to re-optimize their statutory tax rates in a non-cooperative fashion. Indeed we find that countries compete more aggressively via statutory tax rates when thin capitalization rules are coordinated. The partial policy coordination is nevertheless beneficial because tax competition occurs primarily through thin capitalization rules, which can be targeted directly at attracting internationally mobile capital.

This finding implies that regulations specifically addressed at multinational corporations, such as thin capitalization rules, may be a more important determinant of foreign direct investment (FDI) than the statutory tax rate. This prediction receives some support from recent empirical studies. Altshuler and Grubert (2006) show that the U.S. statutory tax rate ceased to have a significant impact on FDI flows, after the United States had effectively relaxed their thin capitalization rules in 1997 (see above). Related evidence is reported in Buettner et al. (2008). They find, for a sample of 24 OECD countries, that thin capitalization rules are effective in reducing firms' debt-to-equity ratios and thus have the potential to reduce international debt shifting. At the same time, the study also finds that the existence and the tightness of thin capitalization rules have significant, adverse effects on foreign direct investment.

Our second main result pertains to the case of asymmetric countries. We analyze different scenarios of asymmetric tax competition and show, inter alia, that the country with 
the smaller population size not only chooses the lower tax rate but also the more lenient thin capitalization rule. This is because the smaller country faces the more elastic tax base for internationally mobile capital, but the same is not true for internationally immobile capital. Hence the small country will find it optimal to tax-discriminate more in favor of mobile, multinational firms. This finding is broadly consistent with stylized facts, which show that large countries, such as Germany, France or the United States have rather elaborate rules limiting the interest-deductibility of internal debt, whereas small countries such as Ireland, Luxembourg and many countries in Eastern Europe have either no thin capitalization rules at all, or very permissive ones (Gouthière, 2005; Dourado and de la Feria, 2008).

The analysis in this paper builds on two strands in the literature. First there are several studies which analyze, theoretically and empirically, the effects of corporate taxation on multinational firms' financing and investment decisions (Mintz and Smart, 2004; Buettner et al., 2008; Schindler and Schjelderup, 2008; Weichenrieder and Windischbauer, 2008). In these papers, however, the theoretical analysis serves primarily to derive testable hypotheses for the ensuing empirical work and the focus is on the choices made by multinational firms, not those of governments. Hence, in contrast to our paper, the analyses do not endogenize the tax policies of countries competing for FDI.

Second, our analysis also relates to the theoretical literature that investigates whether the abolition of tax preferences for mobile tax bases raises or reduces tax revenues and welfare in the competing countries (Janeba and Peters, 1999; Keen, 2001; Janeba and Smart, 2003; Haupt and Peters, 2005; Bucovetsky and Haufler, 2008). A related analysis is Peralta et al. (2006), who show that countries may have an incentive not to monitor profit shifting in multinational firms. Finally, Slemrod and Wilson (2006) and Hong and Smart (2007) ask whether the presence of tax havens is desirable or not from the perspective of large, high-tax countries, by permitting them to tax mobile and immobile capital differentially. However, none of these theoretical studies addresses thin capitalization rules, or the choice of capital structure within national and multinational firms. ${ }^{5}$ Moreover, as will be discussed below, the policy trade-offs analyzed in this literature differ in important ways from the one studied here.

\footnotetext{
${ }^{5} \mathrm{~A}$ theoretical analysis that explicitly incorporates thin capitalization rules is Fuest and Hemmelgarn (2005). In this paper the thin capitalization rule is exogenously fixed, however, and the focus is on the effects that thin capitalization has on the relationship between corporate and personal income taxation in a union of small open economies.
} 
The remainder of the paper is set up as follows. Section 2 presents the basic framework. In Section 3 we derive the Pareto efficient set of tax policies in the benchmark case where all tax instruments can be coordinated internationally. Section 4 analyzes the non-cooperative choice of statutory tax rates and thin capitalization rules. Section 5 turns to the welfare effects of a partial coordination of thin capitalization rules. Section 6 investigates asymmetric tax competition when countries differ either in size or in per capita endowments. Section 7 concludes.

\section{The model}

We consider a model of capital tax competition in a region of two countries, labelled $A$ and $B$. The population size in country $i=\{A, B\}$ equals $L_{i}$ and, without loss of generality, we normalize the total population size $L=L_{A}+L_{B}$ to one. Hence, the population share in country $i$ is $s_{i}=L_{i} / L=L_{i}$. Initially, we focus on the symmetric case with $s_{A}=s_{B}=0.5$, but we incorporate differences in population (or country) size in Section 6.

An important feature of our model is that it distinguishes between two types of capital, which are affected differently by the tax policy instruments introduced below. Internationally immobile capital can only be invested in the country where its owner resides, whereas internationally mobile capital can be invested in either country. Mobile and immobile units of capital can equivalently be thought of as multinational and national firms. Capital endowments are exogenously given and owned by the residents of the two countries. Each resident in the region owns one unit of mobile capital and $n_{i}>0$ units of immobile capital. Again, we assume in most of our analysis that per capita endowments are the same in both countries $\left(n_{A}=n_{B}=n\right)$, but allow for differences in national capital endowments in Section 6. The two types of capital are perfect substitutes and enter the production of a homogeneous output good in both countries, whose price is normalized to unity. The per capita production function in country $i$ is assumed to be quadratic and given by

$$
f\left(k_{i}\right)=a k_{i}-(b / 2) k_{i}^{2}, \quad a, b>0,
$$

where $k_{i} \in[0, a / b]$ is the total per capita amount of capital used for production in country $i$. We assume that the source principle of capital taxation is effective and 
hence capital is taxed in the country where it is employed. ${ }^{6}$ Moreover, we model the tax as a unit tax on capital, rather than as a proportional tax on its return. It is well known that, in settings of competitive markets, this specification simplifies the algebra without affecting the main results.

Central to our analysis are the financial structure of firms and the associated implications for the corporate tax base. To keep the analysis as simple as possible we assume that capital owners can provide firms either with equity or debt and, in the absence of risk considerations, are indifferent between these two financing instruments. The overall tax payment, however, depends on the mix of debt and equity finance. Our modelling is based on the existing corporate tax codes of virtually all OECD countries, which permit the deduction of interest payments for external debt from the corporate tax base, but do not allow a similar deduction for the cost of equity. ${ }^{7}$

Let us first consider immobile national firms (superscript $n$ ). Denote by $\alpha_{i}^{n} \in[0,1]$ the share of debt financing that is chosen by national firms in country $i$, which is fully deductible from the corporate tax base. We will label this source of finance external debt (i.e., debt owed to independent creditors), in order to distinguish it from internal debt flows within a multinational enterprise, as introduced below. While the financing of capital via external debt will thus confer tax savings to the firm, it is associated with non-tax costs that are discussed in detail in the corporate finance literature (see Myers, 2001, for a survey). Specifically, a high level of external debt raises the possibility of financial distress, including the costs associated with possible bankruptcy. Moreover, a higher default risk will increase agency costs due to conflicting interests between managers and shareholders and, in more complex settings than the one studied here, between shareholders and debtholders of the firm. On the other hand, the agency literature also stresses that some level of external debt may be desirable in order to

\footnotetext{
${ }^{6}$ The source principle applies directly, if countries avoid international double taxation by exempting foreign-earned income from domestic tax. This is true for the majority of OECD members but several countries, notably the United States and the United Kingdom, employ instead an international tax credit. Even in this case, however, foreign-earned profits are not taxed by the residence country until they are repatriated. This gives firms an incentive to defer repatriation, if an additional tax is due in their home country. With the possibility of deferral and similar strategies to avoid home country taxation, the evidence seems to be that the effective residence-based tax rate on foreign subsidiary profits is close to zero, and only source-based taxation is effective (see, e.g. Tanzi, 1995, Ch. 6-7).

${ }^{7}$ The only exception is Belgium, which has introduced a 'notional interest deduction' from its corporate tax base in 2006. For an analysis of such investment-neutral corporate tax schemes in the presence of international profit shifting, see Haufler and Schjelderup (2000).
} 
protect the firm from 'empire building' strategies of its managers. We model these different arguments in a highly stylized way, by specifying a target level of external debt, $\bar{\alpha} \in[0,1]$, at which the firm faces no extra costs of its financial structure. Any deviation from this target level will lead to agency costs that are convex in the distance to the target level $\bar{\alpha}$. For simplicity, we consider quadratic agency costs $\beta\left(\alpha_{i}^{n}-\bar{\alpha}\right)^{2} / 2$ where $\beta>0$ parameterizes the extra costs of a non-optimal financial structure. ${ }^{8}$

Let $t_{i}$ be the statutory tax rate in country $i$. The effective tax rate faced by the domestic firm in country $i$ is then $\tau_{i}^{n}=t_{i}\left(1-\alpha_{i}^{n}\right)$. By using (1), the net return to immobile capital in country $i$ (provided either as debt or as equity) reads

$$
r_{i}^{n}=f^{\prime}\left(k_{i}\right)-\tau_{i}^{n}-\frac{\beta}{2}\left(\alpha_{i}^{n}-\bar{\alpha}\right)^{2}=a-b k_{i}-t_{i}\left(1-\alpha_{i}^{n}\right)-\frac{\beta}{2}\left(\alpha_{i}^{n}-\bar{\alpha}\right)^{2} .
$$

The firm then chooses the share of external debt so as to maximize the common net return to its shareholders and bondholders. This yields

$$
\alpha_{i}^{n}=\bar{\alpha}+\frac{t_{i}}{\beta} .
$$

In the firm's financial optimum the tax benefits of a higher level of external debt are traded off against the agency costs. Hence the debt ratio chosen by the firm is a falling function of the agency cost parameter $\beta$ and a rising function of the tax rate $t_{i}{ }^{9}$

Inserting (2) into $\tau_{i}^{n}$ and $r_{i}^{n}$ gives the effective tax rate in the national firms' optimum

$$
\tau_{i}^{n}=t_{i}\left(1-\bar{\alpha}-\frac{t_{i}}{\beta}\right)
$$

and the net return to immobile capital in country $i$

$$
r_{i}^{n}=a-b k_{i}-t_{i}\left(1-\bar{\alpha}-\frac{t_{i}}{2 \beta}\right)
$$

as functions of the tax rate $t_{i}$ and per capita investment $k_{i}$ in country $i$.

The fact that the corporation tax distorts the financing decisions of internationally immobile firms implies that no lump-sum taxes exist in our model. Hence, a nondistortive tax policy cannot simply be achieved by fully exempting mobile capital from tax. It should also be emphasized that our analysis of the tax advantages of external

\footnotetext{
${ }^{8}$ Our specification includes a zero target level of debt $(\bar{\alpha}=0)$ as a special case. For a similar modelling of agency costs see, e.g. Schindler and Schjelderup (2008).

${ }^{9}$ Empirical evidence for the positive relationship between the statutory tax rate and the share of external debt is given in Gordon and Lee (2001).
} 
debt is confined to the level of the corporation and ignores the different tax treatment of equity and debt finance at the shareholder level. There is a general agreement in the literature, however, that a tax advantage of debt is still present, though reduced in size, when personal income taxes are also taken into account. ${ }^{10}$

Let us now turn to the multinational enterprise (MNE). It is assumed that external debt finance has the same tax advantages and the same costs for the multinational as for the domestic firm. However, the MNE has the additional opportunity to engage in financial transactions between its affiliates. We focus on the role such transactions play in minimizing the aggregate tax burden. Hence we assume that the MNE in each of countries $A$ and $B$ can set up a financial subsidiary in a tax haven country $C$, which offers a zero tax rate on capital income. Furthermore, suppose the subsidiary in country $C$ can make an intra-company loan to the producing subsidiary, which is located in either country $A$ or $B$. The interest paid for this loan is deductible in the country of production, whereas the interest income of the financial affiliate in the tax haven is taxed at a zero rate. Hence, the net effect of this triangular structure is to remove the share of capital that is financed by internal (i.e., intra-company) debt from the corporate tax base of the multinational firm. ${ }^{11}$

We further assume that internal debt financing is not associated with agency costs, or costs of financial distress, because the overall liquidity of the MNE is unaffected by the transaction. ${ }^{12}$ The lack of agency costs implies that the ratio of internal debt chosen by the MNE in country $i$ will always be at the maximum of what is permitted by the thin capitalization rules of this country. We thus model a thin capitalization rule (TCR) as an upper limit on the share of intra-firm debt that the multinational firm receives from a subsidiary in the tax haven and that can be deducted from the MNE's tax base in the home country. The permitted share of deductible intra-firm debt is denoted by

\footnotetext{
${ }^{10}$ When taxes at the shareholder level are incorporated, the effective tax rate on capital financed by debt equals the personal income tax rate of the investor, whereas the tax rate on equity equals the sum of corporation and capital gains taxes (provided that no dividends are paid out). See Auerbach (2002) for more details and Fuest and Hemmelgarn (2005) for an analysis of tax competition when governments can choose both corporate and personal income taxes (but not thin capitalization rules).

${ }^{11}$ See Mintz (2004) and OECD (2007, chap. 5) for more detailed descriptions of triangular, or 'conduit' financing structures used by MNEs.

${ }^{12}$ This assumption is clearly a simplification, but it is supported by empirical evidence that the costs of a higher debt-asset ratio are substantially reduced when the debt is owed to an affiliated company (see Desai et al., 2004).
} 
$\lambda_{i} \in[0,1]$ and we restrict it to be non-negative. ${ }^{13}$

At first sight, our modelling of TCRs as a threshold that applies exclusively to internal debt seems to differ from the thin capitalization rules of several OECD countries, which restrict the sum of internal and external debt. In the United States, for example, the permitted debt-to-equity ratio is 1.5 to 1 , corresponding to a share of $60 \%$ of the firm's capital being financed by debt. If a company stays below this threshold, all interest payments will automatically be tax-deductible. The rationale behind this safe haven approach is that the distinction between internal and external debt is often difficult to draw in practice and hence it is administratively easier to specify an acceptable share of overall debt for each affiliate. However, when a company's debt-to-equity ratio is above the safe-haven ratio, so that it comes to restricting the level of deductible debt, then the distinction between internal and external debt is drawn and deductibility is denied only for internal loans. Hence, the final choice parameter of governments is indeed the deductible share of internal debt, as specified in our analysis.

The effective tax rate on immobile firms (superscript $m$ ) in country $i$ is then $\tau_{i}^{m}=$ $t_{i}\left(1-\alpha_{i}^{m}-\lambda_{i}\right)$, where $\alpha_{i}^{m}$ is the share of external debt of a mobile firm in country $i$. The net return to a unit of mobile capital in country $i$, provided either as equity or as debt, reads

$$
r_{i}^{m}=f^{\prime}\left(k_{i}\right)-\tau_{i}^{m}-\frac{\beta}{2}\left(\alpha_{i}^{m}-\bar{\alpha}\right)^{2}=a-b k_{i}-t_{i}\left(1-\alpha_{i}^{m}-\lambda_{i}\right)-\frac{\beta}{2}\left(\alpha_{i}^{m}-\bar{\alpha}\right)^{2} .
$$

Maximizing this expression with respect to the MNE's share of external debt yields $\alpha_{i}^{m}=\bar{\alpha}+t_{i} / \beta$, and hence the same decision rule as for national firms [cf. eq. (2)]. The maximum permissible share of internal debt, $\lambda_{i}$, is instead set by the government of country $i$, and is fully exploited by the multinational in its financial optimum. Hence, the MNE's effective tax rate is lower than that of domestic firms, whenever a positive allowance is also made for internal debt (i.e., $\lambda_{i}>0$ ). Using the optimized value for $\alpha_{i}^{m}$, the effective tax rate on mobile firms in country $i$ can be written as

$$
\tau_{i}^{m}=t_{i}\left(1-\lambda_{i}-\bar{\alpha}-\frac{t_{i}}{\beta}\right),
$$

yielding a net return to mobile capital equal to

$$
r_{i}^{m}=a-b k_{i}-t_{i}\left(1-\lambda_{i}-\bar{\alpha}-\frac{t_{i}}{2 \beta}\right) .
$$

\footnotetext{
${ }^{13}$ Allowing for negative values of $\lambda_{i}$ would imply that countries could effectively restrict the taxdeductibility of external debt for multinational firms, but not for domestic firms. This is clearly incompatible with current principles of corporate income taxation.
} 
These expressions show that MNEs are affected by both policy instruments in our analysis. In particular, a tightening of the TCR (a reduction in $\lambda_{i}$ ) raises the effective tax rate and reduces the net return to mobile capital in this country.

In a capital market equilibrium, the worldwide capital demand must equal the sum of mobile and immobile capital endowments. Expressed in per capita terms, we obtain

$$
s_{A} k_{A}+s_{B} k_{B}=1+s_{A} n_{A}+s_{B} n_{B} .
$$

Moreover, international arbitrage has to ensure that the net return to mobile capital is the same in the two countries. Setting $r_{A}^{m}=r_{B}^{m}$ in (6) and using (7) yields

$$
k_{i}=1+s_{i} n_{i}+s_{j} n_{j}+\frac{s_{j}}{b}\left[t_{j}\left(1-\lambda_{j}-\bar{\alpha}-\frac{t_{j}}{2 \beta}\right)-t_{i}\left(1-\lambda_{i}-\bar{\alpha}-\frac{t_{i}}{2 \beta}\right)\right],
$$

with $i, j \in\{A, B\}$ and $i \neq j$. Equation (8) shows that an increase in country $i$ 's statutory tax rate and a tightening of its TCR both induce a capital outflow from country $i$ to country $j$.

Each resident in country $i$ consumes the numéraire output good in quantity $x_{i}$. Per capita after-tax income is composed of the net returns from the endowments of mobile and immobile capital and the residual remuneration of an inelastically supplied factor of production (e.g. labor). The latter equals the value of domestic output, less the competitive payments to all capital inputs. Hence per capita private consumption is

$$
x_{i}=n_{i} r_{i}^{n}+r_{i}^{m}+f\left(k_{i}\right)-f^{\prime}\left(k_{i}\right) k_{i}=n_{i} r_{i}^{n}+r_{i}^{m}+\frac{b}{2} k_{i}^{2} .
$$

Each government collects taxes from both mobile and immobile capital. Mobile capital employed in country $i$ is given by $k_{i}-n_{i}$. Per capita tax revenue in country $i$ is thus

$$
z_{i}=\tau_{i}^{m}\left(k_{i}-n_{i}\right)+\tau_{i}^{n} n_{i}=\tau_{i}^{m} k_{i}+n_{i} t_{i} \lambda_{i}
$$

where the second step has used $\tau_{i}^{n}-\tau_{i}^{m}=t_{i} \lambda_{i}$ from (3) and (5).

To specify national welfare, we assume a fixed marginal rate of substitution between private and public consumption where each Euro of tax revenue is worth $1+\varepsilon$ Euros of private income (with $\varepsilon>0$ ). This specification ensures that both countries levy positive capital taxes in equilibrium. One way to motivate this specification is to think of $z_{i}$ as a public good with a constant marginal valuation (in terms of the private numéraire good) that exceeds its cost. Alternatively, there is another distortionary tax in the background to finance public goods (a personal income tax, or a value-added 
tax), and this other tax has a marginal excess burden of $\varepsilon$. Revenue collections from the corporation tax thus allow to reduce the distortions resulting from this other tax, while keeping public good supply constant. Finally, a still different interpretation is that policy makers want to attract voters that perceive corporate taxes as being 'too low', and hence attach an extra value of $\varepsilon$ to each Euro collected from corporation tax. Per capita welfare in country $i$ is then defined as

$$
u_{i}=x_{i}+(1+\varepsilon) z_{i}=n_{i} r_{i}^{n}+r_{i}^{m}+\frac{b}{2} k_{i}^{2}+(1+\varepsilon)\left(\tau_{i}^{m} k_{i}+n_{i} t_{i} \lambda_{i}\right),
$$

where $r_{i}^{n}$ and $r_{i}^{m}$ must be substituted from (4) and (6), the effective tax rates $\tau_{i}^{n}$ and $\tau_{i}^{m}$ are given in (3) and (5) and $k_{i}$ is given in (8).

\section{Benchmark: Pareto efficient tax policy}

As a benchmark, we derive the Pareto efficient tax policy when countries $A$ and $B$ can fully coordinate both their tax rates and their thin capitalization rules. In this and the following two sections we focus on the symmetric case with $s_{A}=s_{B}=0.5$ and $n_{A}=n_{B}=n$. Hence we can assume that each country sets its tax policy so as to maximize the sum of utilities, $u_{A}+u_{B}$. Denoting the Pareto efficient policy by the superscript $P O$, the appendix shows that

$$
t^{P O}=\frac{\beta \varepsilon(1-\bar{\alpha})}{1+2 \varepsilon}, \quad \lambda^{P O}=0 .
$$

These results can be explained as follows. In a symmetric situation, common changes in the tax instrument affect neither the distribution nor the aggregate amount of capital. Hence, relaxing the common thin capitalization rule by increasing $\lambda_{i}$ only has the effect of lowering each country's tax base. This increases the net return obtained by mobile capital, but it reduces tax revenues by the same amount. Since tax revenues have the higher weight in the national welfare functions (as reflected by $\varepsilon>0$ ), it is thus never optimal to increase $\lambda_{i}$ above zero. In contrast, the Pareto efficient statutory tax rate is always positive. It is optimized when the marginal excess burden of corporate taxation, which is caused by national and multinational firms choosing inefficiently high levels of external debt finance, is equated to the extra value of corporate tax revenue. For this reason, $t^{P O}$ is rising in $\varepsilon$. Moreover, it is rising in the agency cost parameter $\beta$, because high costs of financial distress make it unattractive for firms to pursue a high-debt policy for tax reasons, thus reducing the elasticity with which the corporate tax base responds to the statutory tax rate. 


\section{Tax competition}

Let us now turn to the case where the two governments in $A$ and $B$ simultaneously and non-cooperatively choose their tax policies. We assume that tax rates and thin capitalization rules are chosen simultaneously, implying that they are equally flexible instruments from the perspective of each government. This specification is supported by several recent corporate tax reforms, such as the German and Irish reforms mentioned in the introduction, where tax rates and thin capitalization restrictions were changed simultaneously or immediately following one another. It can also be argued that the U.S. tax code changes in 1997 represented an imperfect substitute for a reduction in the statutory tax rate (and, as we will see, a superior adjustment from a national perspective), as it allowed the United States to maintain a statutory tax rate substantially above the OECD average, despite increasing competition for mobile capital.

With these assumptions, country $i$ maximizes its per capita welfare (11) with respect to its policy instruments $t_{i}$ and $\lambda_{i}$, taking as given the choices of $t_{j}$ and $\lambda_{j}$ in country

$j \neq i$. The tax policies in the symmetric Nash equilibrium of the tax competition game are derived in the appendix and given by

$$
\begin{gathered}
t^{*}=\frac{\beta \varepsilon n(1-\bar{\alpha})}{(1+\varepsilon)(1+n)+\varepsilon n}, \\
\lambda^{*}=\frac{(1+\varepsilon)(1+n)(1-\bar{\alpha})}{(1+\varepsilon)(1+n)+\varepsilon n}-\frac{2 b[(1+\varepsilon)(1+n)+\varepsilon n]}{\beta n(1+\varepsilon)(1-\bar{\alpha})} .
\end{gathered}
$$

Equation (13) shows that the equilibrium tax rate is positive whenever there is a positive excess value of corporate tax revenue $(\varepsilon)$. In contrast, the equilibrium level of the thin capitalization rule is composed of a positive and a negative term. An interior solution $\left(\lambda^{*}>0\right)$ will only be an equilibrium when the second term in (14) is sufficiently small. This is true, in particular, when the parameter $b$ is small, so that mobile capital responds elastically to the effective tax rates [see equation (8)]. A low value of $b$ thereby leads to strong incentives for each country to underbid the effective tax rate of its neighbor by relaxing the thin capitalization rule (i.e., by raising $\lambda_{i}$ ). In the following we will assume that tax competition is sufficiently 'strong' in this sense. Note also that the permitted share of internal debt is always less than $1-\bar{\alpha}$, since the first term in (14) is less than this value, and the second term is negative.

We are now in the position to compare the tax policies in the non-cooperative Nash equilibrium with the Pareto efficient taxes under full policy coordination: 
Proposition 1 Suppose $s_{A}=s_{B}=0.5, n_{A}=n_{B}=n$ and the tax competition game attains a symmetric Nash equilibrium. Then the statutory tax rate is inefficiently low $\left(t^{*}<t^{P O}\right)$. Moreover, if tax competition is sufficiently strong (b is sufficiently low), then the equilibrium thin capitalization rule is inefficiently lax $\left(\lambda^{*}>\lambda^{P O}=0\right)$.

Proof: Follows directly from comparing (12) with (13) and (14).

The first part of Proposition 1 is a standard result in the tax competition literature. Our focus is on the second part, which highlights the role of the thin capitalization rule as a policy instrument in the tax competition for mobile capital. Relaxing the TCR (increasing $\lambda_{i}$ ) reallocates income from the public sector to the private sector. This effect on its own is welfare-reducing for each country, for the reasons discussed above. When tax policies are non-cooperatively chosen, however, increasing $\lambda_{i}$ attracts mobile capital from the neighboring country. Moreover, in contrast to the statutory tax rate, this instrument can be targeted directly at mobile, multinational firms. Hence, a policy of lenient thin capitalization rules can attract capital at a lower cost, in terms of the foregone tax revenue, than when only the (non-discriminatory) statutory tax rate is used for this purpose. This positive tax allowance for internal debt implies that MNEs will be tax-favored in the non-cooperative Nash equilibrium, relative to nationally operating firms.

Importantly for the ensuing analysis, common changes in the exogenous parameters of our model affect the policy instruments in the non-cooperative tax equilibrium in very different ways. To see this in more detail, we compute the effective tax rates on mobile and immobile firms by substituting (13) and (14) into (3) and (5). This yields

$$
\tau^{n *}=\frac{\varepsilon \beta n(1-\bar{\alpha})^{2}(1+\varepsilon)(1+n)}{[(1+\varepsilon)(1+n)+\varepsilon n]^{2}}, \quad \tau^{m *}=\frac{2 b \varepsilon}{1+\varepsilon} .
$$

We can then immediately state:

Proposition 2 In a symmetric tax competition equilibrium with $\lambda_{i}^{*}>0$, the following holds: ( $i$ ) A higher degree of international tax base mobility (a fall in b) reduces the effective tax rate on mobile firms, but does not change the effective tax rate on immobile firms. (ii) A higher domestic tax base elasticity (a fall in $\beta$ ) reduces the effective tax rate on national firms, but leaves the effective tax rate on mobile firms unchanged.

Proof: Follows directly from eq. (15).

The reason for part $(i)$ of Proposition 2 is that more intensive tax competition (a fall in $b$ ) induces each country to relax its thin capitalization rule [according to (14)], but it 
does not alter statutory tax rates [eq.(13)]. Hence this parameter change unambiguously increases the degree of tax discrimination in favour of MNEs, which can be expressed as $\tau^{n *}-\tau^{m *}=t^{*} \lambda^{*}$. By relaxing only the TCR, tax concessions can be targeted at the base that has become more mobile internationally, thus avoiding any revenue loss from the taxation of national firms. Conversely, the rationale for part ( $i i)$ of the proposition is that a reduction in the cost parameter for external debt (a fall in $\beta$ ) lowers the statutory tax rate and thus the effective taxation of national firms. For multinational firms, however, this reduction is fully compensated by a tightening of the TCR. The reason is that, with $\lambda_{i}^{*}>0$, the international mobility of the tax base is the binding constraint for the effective taxation of mobile firms, and this constraint is unaffected if the (domestic) costs of external indebtedness are reduced. In sum, therefore, eq. (15) shows that the effective tax rate on national firms is driven by the agency costs of higher external debt, whereas the tax rate on multinational firms is solely determined by the degree of international tax base mobility.

\section{Partial coordination of thin capitalization rules}

In the previous section we have seen that tax competition will lead to inefficiently low tax rates and inefficiently lax thin capitalization rules. In this section we thus consider the effects of a coordinated tightening of TCRs in both countries. At the same time we assume that each country is free to adjust its tax rate in a nationally optimal way to the new thin capitalization restrictions. This partial policy coordination is the relevant scenario in the EU, where the European Commission proposes to introduce coordinated thin capitalization rules within the framework of the Common Consolidated Corporate Tax Base, but simultaneously emphasizes that member states remain free to set their tax rates autonomously (see Fuest, 2008). Outside the EU, it is even more obvious that any attempt to coordinate TCRs in order to combat international debt shifting by MNEs will not be accompanied by simultaneous restrictions on countries' corporate tax rates. The constraint that not all policy instruments can be chosen in a coordinated fashion opens up the possibility that countries respond to the coordinated tightening of thin capitalization rules by competing more aggressively via statutory tax rates. Since this will also reduce the taxation of immobile firms, the welfare effects of a partial coordination of TCRs are ambiguous a priori.

In analyzing this issue in our framework, we maintain the assumption of fully symmetric 
countries. Under this assumption, we determine the total change in country $j$ 's utility caused by a marginal reduction in both countries' thin capitalization variable. Formally, we set $\mathrm{d} \lambda_{i}=\mathrm{d} \lambda_{j}=\mathrm{d} \lambda<0$. The total change in country $j$ 's welfare then reads ${ }^{14}$

$$
\frac{\mathrm{d} u_{j}}{\mathrm{~d} \lambda}=\frac{\partial u_{j}}{\partial \lambda_{i}}+\frac{\partial u_{j}}{\partial t_{i}} \frac{\mathrm{d} t_{i}}{\mathrm{~d} \lambda}, \quad i \neq j
$$

The total effect of the partial coordination on country $j$ 's welfare is thus composed of a direct effect and an indirect effect. The direct effect measures the impact of the reduction in country $i$ 's thin capitalization variable $\lambda_{i}$ on country $j$ 's welfare. The indirect effect works through the impact of the partial coordination of TCRs on country $i$ 's tax rate, and the resulting effect of the change in $t_{i}$ on country $j$ 's welfare. Note that the expression $\mathrm{d} t_{i} / \mathrm{d} \lambda$ is the response of country $i$ 's statutory tax rate to the simultaneous changes in $\lambda_{i}$ and $\lambda_{j}$.

The direct effect is obtained from differentiating (11) as

$$
\frac{\partial u_{j}}{\partial \lambda_{i}}=-\frac{(1+\varepsilon) \tau^{m, *} t^{*}}{2 b}<0 \quad i \neq j
$$

Hence, the direct effect of a small reduction in $\lambda_{i}$ is beneficial for country $j$. An isolated tightening of country $i$ 's TCR increases the effective tax rate on mobile capital in this country and leads to a reallocation of mobile capital to country $j$.

Similarly, a statutory tax increase in country $i$ also benefits the neighboring country $j$. This is seen from (11), which implies

$$
\frac{\partial u_{j}}{\partial t_{i}}=\frac{(1+\varepsilon) \tau^{m, *}}{2 b}\left(1-\bar{\alpha}-\lambda^{*}-\frac{t^{*}}{\beta}\right)>0 \quad i \neq j .
$$

To determine the overall sign of the indirect effect in (16), we have to establish whether partial policy coordination increases or decreases country $i$ 's statutory tax rate. It is shown in the appendix that

$$
\frac{\mathrm{d} t_{i}}{\mathrm{~d} \lambda}=\frac{\varepsilon(1+\varepsilon) \beta^{2} n^{2}(1-\bar{\alpha})^{2}}{\Delta}>0,
$$

with

$$
\Delta=(1+n+2 \varepsilon n) n^{2}(1-\bar{\alpha})^{2} \beta(1+\varepsilon)+2 b(1+n+\varepsilon+2 \varepsilon n)^{2}>0 .
$$

Hence each country responds to the coordinated tightening of thin capitalization rules $(\mathrm{d} \lambda<0)$ by lowering its statutory tax rate. Intuitively, as the partial policy coordination restricts each country's ability to attract mobile capital by means of lax TCRs, tax

\footnotetext{
${ }^{14}$ In deriving (16) we used the first-order conditions $\partial u_{j} / \partial t_{j}=0$ and $\partial u_{j} / \partial \lambda_{j}=0$, since both instruments were chosen optimally from country $j$ 's perspective before the variation in TCRs.
} 
competition will shift to a more aggressive lowering of statutory corporate tax rates. Together with (18) this implies that the indirect effect of a coordinated tightening of TCRs in (16) is negative and counteracts the direct effect.

Can the net welfare effect of the coordination measure nevertheless be signed? In our model it turns out that the direct effect of a tightening of thin capitalization rules always dominates the indirect effect. Substituting (17)-(20) in (16) and rearranging terms gives

$$
\frac{\mathrm{d} u_{j}}{\mathrm{~d} \lambda}=-\frac{(1+\varepsilon) \tau^{m, *}}{2 b \Delta} \frac{\varepsilon n(1-\bar{\alpha})(1+n+2 \varepsilon n)}{(1+n+\varepsilon+2 \varepsilon n)}<0 .
$$

This yields one of the main results of our analysis:

Proposition 3 Starting from a symmetric Nash equilibrium of the tax competition game, a coordinated tightening of thin capitalization rules increases welfare in both countries, even though statutory tax rates in both countries are simultaneously reduced.

To see why the partial coordination of TCRs is mutually welfare-increasing, despite the simultaneous reduction in statutory tax rates, we return to the properties of the Nash equilibrium discussed in the previous section (Proposition 2). We have seen there that international tax competition for mobile capital occurs primarily through thin capitalization rules, which can be targeted directly at the internationally mobile tax base. The statutory tax rate, while also being affected by international tax competition, will instead balance the overall efficiency losses from the corporation tax (caused by both an excess use of external debt and an international capital outflow) against the extra value of corporate tax revenues. Hence restricting the use of TCRs through international policy coordination deprives countries of their most aggressive instrument in international tax competition. Therefore, a coordinated increase in TCRs reduces the overall intensity of tax competition, and hence also the associated welfare losses.

Proposition 3 implies that restricting the use of discriminatory tax policies is collectively welfare-increasing in our model, even if not all policy instruments can be coordinated. It is therefore worthwhile to briefly compare our model to the literature analyzing the abolition of preferential tax regimes (Janeba and Peters, 1999; Keen, 2001; Janeba and Smart, 2003; Haupt and Peters, 2005). This literature uses a model where each of two tax bases, which differ in their degree of international mobility, is taxed by a separate instrument. The policy question asked is then whether tax revenues will be raised or lowered when countries are forced to choose the same tax rate on both tax bases. As shown by Janeba and Smart (2003), the net revenue effect of this measure 
will depend, in general, on the elasticities with which the different tax bases respond to unilateral and coordinated changes in tax rates. ${ }^{15}$ The core difference in the present model is that the mobile tax base is simultaneously affected by both policy instruments considered, and both are distorted in the direction of an insufficient taxation of capital in the initial, non-cooperative equilibrium. Hence, the welfare effects of the partial coordination measure do not depend primarily on (a comparison of) tax base elasticities, but on the question of whether the coordinated policy instrument is the one that is more closely targeted at the internationally mobile tax base in the unconstrained tax competition equilibrium.

\section{$6 \quad$ Asymmetries between countries}

So far, our analysis has focused on the special case where the two countries are identical in all respects. There are, however, a number of relevant asymmetries among countries and it is interesting to analyze how such differences affect equilibrium tax rates and thin capitalization rules. As in much of the tax competition literature, discrete differences in country characteristics are difficult to handle analytically in our framework. Our model is simple enough, however, to permit some important analytical insights by focusing on small differences between the two countries. In the following we first analyze crosscountry differences in population size and then turn to the case where countries have different per capita endowments of (internationally immobile) capital.

Starting from an initially symmetric Nash equilibrium of the tax competition game, we analyze the effects of a marginal decrease in country $i$ 's population size, which is accompanied by an equal increase in the population size of country $j$. To isolate the effects of country size we maintain equal per capita endowments for the residents of both counties $\left(n_{i}=n_{j}=n\right)$. Hence, when decreasing (increasing) the population size of country $i(j)$ we simultaneously and proportionally reduce (raise) this country's capital stock. Formally, we compute the effects of $\mathrm{d} s_{i}=-\mathrm{d} s_{j}<0$ and evaluate these effects

\footnotetext{
${ }^{15}$ Bucovetsky and Haufler (2008) consider a model of tax discrimination when governments choose a tax rate and a tax preference parameter for the mobile base. In this model the size of the mobile and the immobile tax base is not given exogenously and the trade-off for tax policy is a still different one. Reducing the degree of tax discrimination in favor of mobile capital reduces the effective tax rate on both mobile and immobile capital, but at the same time it also reduces the incentives for firms to invest in a tax-favored multinational structure. The welfare effects of a coordinated reduction in tax preferences then depend on the elasticity with which firms can change their organizational form.
} 
at the symmetric equilibrium $\left(s_{i}=s_{j}=0.5\right)$, as characterized in Section 4 . It is shown in the appendix that

$$
\begin{gathered}
\frac{\mathrm{d}\left(t_{i}-t_{j}\right)}{\mathrm{d} s_{i}}=\frac{1}{|J|} \frac{4 n^{2} \beta \varepsilon^{3}(1+\varepsilon)(1-\alpha)^{2}}{b(1+n+2 \varepsilon n+\varepsilon)^{2}}>0, \\
\frac{\mathrm{d}\left(\lambda_{i}-\lambda_{j}\right)}{\mathrm{d} s_{i}}=-\frac{1}{|J|} \frac{4 \varepsilon(1+n+2 \varepsilon n-\varepsilon)}{\beta}<0 \quad \text { for } 1+n+2 n \varepsilon-\varepsilon>0,
\end{gathered}
$$

where $|J|>0$ is given in eq. (A.18) in the appendix.

Equation (22) shows that the smaller country imposes a lower statutory tax rate and thus also has a lower effective tax rate on domestic firms than the larger country. The effect of country size on (the difference in) thin capitalization rules depends on the sign of $1+n+2 n \varepsilon-\varepsilon$ and is thus not unambiguous when $\varepsilon$ can become arbitrarily large. However, a sufficient conditions for this term to be positive is that the extra value of one unit of corporate tax revenue is less than 100 percent. ${ }^{16}$ Our further analysis is based on this case where $\varepsilon$ is not too high. A fall in $s_{i}$ will then lead to a more lenient TCR in the smaller country (a higher level of $\lambda_{i}$ ), in comparison to the policy of the larger neighbor $j$. With a lower statutory tax rate and a lower tax base in the smaller country, we also get the unambiguous result that the smaller country levies the lower effective tax rate on mobile firms. These results are summarized in:

Proposition 4 Starting from a symmetric tax competition equilibrium, suppose that the population size of one country is increased while the size of the other country is reduced by the same amount. In the asymmetric Nash equilibrium, the smaller country then levies the lower statutory tax rate. If $\varepsilon$ is not too large $(\varepsilon<1)$, then the smaller country also chooses the more lenient thin capitalization rule.

The first part of this proposition is in accordance with the results of the asymmetric tax competition models in Bucovetsky (1991) and Wilson (1991). They show that, with equal per capita endowments, the smaller country faces a higher elasticity of the mobile capital tax base with respect to its own tax rate and hence finds it optimal to choose the lower (effective) tax rate. The additional result in Proposition 4 is that the smaller country will also offer mobile firms the larger reduction in their tax base and thus discriminates more in favor of MNEs. This is again a result of targeting. In comparison to its larger neighbor, the small country faces the higher tax base elasticity only for mobile, but not for immobile firms. Hence, offering a more generous TCR

\footnotetext{
${ }^{16}$ An alternative sufficient condition is $n \geq 0.5$.
} 
Table 1: Simulation results for tax competition with asymmetric country size

\begin{tabular}{|ccccc|cccccccc|}
\hline \multicolumn{4}{|c|}{ parameters } & \multicolumn{8}{|c|}{ endogenous variables } \\
\hline & $s_{A}$ & $\varepsilon$ & $b$ & $\beta$ & $\lambda_{A}$ & $\lambda_{B}$ & $t_{A}$ & $t_{B}$ & $\tau_{A}^{m}$ & $\tau_{B}^{m}$ & $\tau_{A}^{n}$ & $\tau_{B}^{n}$ \\
\hline$(1)$ & 0.5 & 0.3 & 0.5 & 2.0 & 0.151 & 0.151 & 0.433 & 0.433 & 0.231 & 0.231 & 0.296 & 0.296 \\
\hline$(2)$ & 0.4 & 0.3 & 0.5 & 2.0 & 0.186 & 0.092 & 0.434 & 0.439 & 0.216 & 0.258 & 0.296 & 0.299 \\
\hline$(3)$ & 0.4 & 0.4 & 0.5 & 2.0 & 0.129 & 0.038 & 0.532 & 0.539 & 0.268 & 0.319 & 0.337 & 0.340 \\
\hline$(4)$ & 0.4 & 0.3 & 0.4 & 2.0 & 0.266 & 0.184 & 0.396 & 0.401 & 0.173 & 0.207 & 0.278 & 0.280 \\
\hline$(5)$ & 0.4 & 0.3 & 0.5 & 3.0 & 0.325 & 0.252 & 0.552 & 0.559 & 0.216 & 0.258 & 0.395 & 0.399 \\
\hline
\end{tabular}

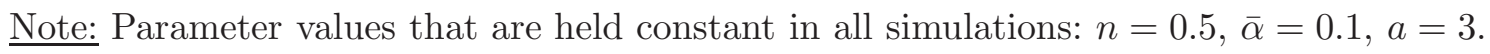

in comparison to its neighbor allows the small country to compete aggressively for internationally mobile capital, while at the same time limiting the tax revenue loss from a reduced taxation of its immobile tax base.

To illustrate the workings of our model with differences in country size, and to test whether the analytical findings continue to hold for large asymmetries, we carry out a set of simulation analyses. The results are shown in Table 1. Row (1) in the table gives the results for the symmetric benchmark case. In row (2) an asymmetry is introduced by reducing the relative size of country $A$ to $s_{A}=0.4$ (and hence $s_{B}=0.6$ ). The simulations show that the small country reduces its statutory tax rate only slightly below that of its larger neighbor, but chooses a much more generous thin capitalization rule. This result confirms our earlier argument that the competition for mobile capital occurs mainly through thin capitalization rules in the present model. In row (3) the extra value of corporate tax revenue $(\varepsilon)$ is raised in both countries. This leads to tighter thin capitalization rules (reduced levels of $\lambda_{i}$ ) and higher statutory tax rates in both countries, as compared to the results in row (2). In line (4) a higher elasticity of the mobile tax base and more aggressive tax competition is analyzed through a reduction in the curvature parameter $b$ of both countries' production functions. This relaxes thin capitalization rules and reduces statutory tax rates in both countries. In row (5), an increase in the agency costs of internal debt (a rise in $\beta$ ) causes an increase in the statutory tax rate that is fully compensated for mobile firms by a simultaneous increase in $\lambda$. Hence the result that $\tau_{i}^{m}$ is independent of $\beta$ [see eq. (15)] holds also in the case of asymmetric countries. Finally, in all asymmetric equilibria the smaller country levies the lower statutory tax rate and offers the more generous thin capitalization allowance, as stated in our analytical result in Proposition 4. 
We now turn to differences in the per capita endowments of immobile capital $n_{i}$ while assuming countries of equal population size $\left(s_{A}=s_{B}=0.5\right)$. Hence we consider tax competition between capital-rich versus capital-poor countries. Again, we start from an initially symmetric equilibrium and analyze the effects of a marginal increase in $n_{i}$ on the difference in the non-cooperatively chosen tax policies. In this analysis we focus on the effective tax rates as summary measures of the tax burden on mobile and immobile capital. This gives the following results, which are derived in the appendix:

$$
\frac{\mathrm{d}\left(\tau_{i}^{n}-\tau_{j}^{n}\right)}{\mathrm{d} n_{i}}>0, \quad \frac{\mathrm{d}\left(\tau_{i}^{m}-\tau_{j}^{m}\right)}{\mathrm{d} n_{i}}<0 .
$$

Hence we get:

Proposition 5 In an asymmetric tax competition equilibrium with small differences in the per capita endowments with immobile capital, the capital-rich country levies a higher effective tax rate on immobile capital, but a lower effective tax rate on mobile capital, relative to its capital-poor neighbor.

The first part of Proposition 5 is immediately intuitive. An increase in, say, $n_{A}$ raises the immobile tax base in country $A$ and this makes it attractive for this country's government to raise the statutory capital tax rate, and hence also the effective tax rate on national firms. The second part of Proposition 5 is more surprising, however. Even though country $A$ has the higher statutory tax rate, its effective tax rate on mobile capital falls below that of country $B$. To understand this result, note that the marginal productivity of capital falls in country $A$ when this country has the larger domestic capital stock. This places country $A$ at a disadvantage vis-à-vis country $B$ in the competition for mobile firms. To partly compensate for the lower gross return, country $A$ thus offers a lower effective tax rate to mobile firms. Since the statutory tax rate is simultaneously increased, this can only be brought about by a strong relaxation of the TCR, which more than compensates mobile firms for the increase in the statutory tax rate. Hence the country with the larger per-capita stock of (immobile) capital unambiguously discriminates more in favor of MNEs than its capital-poorer neighbor.

\section{Conclusions}

This paper has introduced a model where countries compete for internationally mobile firms through both statutory tax rates and thin capitalization rules that limit the 
tax-deductibility of internal debt flows within multinational enterprises. Starting from a tax competition equilibrium with inefficiently low tax rates and inefficiently lax thin capitalization rules, we have shown that a coordinated policy of tightening thin capitalization rules will benefit both countries, even though it induces them to compete more aggressively via statutory tax rates. The reason is that tax competition occurs primarily through thin capitalization rules in the present model, whereas statutory tax rates balance the (domestic and international) excess burden of taxation with the extra value of collecting corporate tax revenue. Therefore, even an isolated coordination of thin capitalization rules is an effective way to reduce the overall intensity of corporate tax competition.

These results of our model correspond to some recent developments and empirical findings in the literature. Altshuler and Grubert (2006) provide data for the United States showing that the introduction of "hybrid entities" in 1997, which made it easier for U.S. multinationals to avoid taxes on intercompany payments like interest and royalties, induced a large growth in such payments and substantially increased the disparity in the reported profitability of subsidiaries in high-tax and low-tax jurisdictions. At the same time the authors find that the link between international tax rate differentials and foreign direct investment was significantly weakened by this change in tax rules. This is consistent with the implication of our model that tax competition for multinational firms occurs mostly through tax rules that are explicitly targeted at mobile capital, whereas statutory corporate tax rates may be of secondary importance in this process. The adverse effects of tight thin capitalization restrictions on inward foreign direct investment are confirmed in the recent empirical study by Buettner et al. (2008). In a tax competition environment we can thus expect that countries indeed set their thin capitalization rules less strictly than they otherwise would, for fear of losing foreign direct investment to other regions. At a general level, the results of our model thus support a coordinated tightening of thin capitalization rules, as is envisaged in the recent proposals for corporate tax reform in the European Union.

A well-known problem in international tax coordination is, however, that countries with different characteristics have diverging national interests and individual countries may veto coordination measures, even if the latter are potentially Pareto improving. Our analysis has therefore incorporated asymmetries between countries with respect to population size and per capita endowments with capital. In particular, we have shown that small countries will not only choose lower corporate tax rates, but they 
will also opt for more lenient thin capitalization rules than their larger neighbors. A first look at the thin capitalization regulations in different OECD countries seems to be roughly consistent with this prediction. Moreover, we have shown that countries with larger endowments of (internationally immobile) capital will offer more favorable tax conditions for mobile firms than their capital-poorer neighbors.

Our analysis can be extended in several ways. First, we have assumed that intra-firm financial transactions are exclusively driven by tax considerations while ignoring any non-tax reasons for such flows. Empirical research shows, however, that U.S. multinationals use internal capital markets to overcome market imperfections in the external credit markets of their host countries (see Desai at al., 2004; Buettner et al., 2006). Incorporating such productive purposes of intra-firm financial transactions may have interesting repercussions on the optimal setting of thin capitalization rules. Second, thin capitalization rules may also be driven by 'fairness' considerations, in the sense that (some) governments may perceive an extra benefit of taxing national and multinational firms at similar effective rates. Developing the implications of tax competition between fair-minded governments, or between one government that is fair-minded and one that is not, is a further possible issue for future research. 


\section{Appendix}

\section{A.1. Pareto efficient tax policy}

Symmetry $\left(s_{A}=s_{B}=0.5, n_{A}=n_{B}=n\right)$ implies $t_{A}=t_{B}=t$ and $\lambda_{A}=\lambda_{B}=\lambda$.

Equation (8) then yields $k_{A}=k_{B}=1+n$. Using (3), (4), (5) and (6) in (11), we obtain

$$
\begin{aligned}
u_{A}+u_{B}=2(1+n)[a-b(1+n) & \left.-t\left(1-\bar{\alpha}-\frac{t}{2 \beta}\right)\right]-2 \varepsilon t \lambda \\
& +2 t(1+\varepsilon)(1+n)\left(1-\bar{\alpha}-\frac{t}{\beta}\right) .
\end{aligned}
$$

The derivative of (A.1) with respect to $\lambda$ reads

$$
\frac{\partial\left(u_{A}+u_{B}\right)}{\partial \lambda}=-2 \varepsilon t<0 .
$$

Hence, we obtain the corner solution $\lambda^{P O}=0$ as stated in (12). Inserting $\lambda^{P O}=0$ into (A.1) and differentiating with respect to $t$ gives

$$
\frac{\partial\left(u_{A}+u_{B}\right)}{\partial t}=2(1+n)\left[(1+\varepsilon)\left(1-\bar{\alpha}-\frac{2 t}{\beta}\right)-\left(1-\bar{\alpha}-\frac{t}{\beta}\right)\right]=0 .
$$

Solving this condition with respect to $t$ gives the efficient tax rate $t^{P O}$ in (12).

\section{A.2. Symmetric tax competition}

Differentiating (11) and taking into account (3) $-(8)$ and $s_{i}+s_{j}=1$ yields

$$
\frac{\partial u_{i}}{\partial t_{i}}=s_{i}\left(k_{i}-1-n_{i}\right) \mu_{i}+\varepsilon\left(k_{i} \mu_{i}+n_{i} \lambda_{i}\right)-(1+\varepsilon) t_{i}\left(\frac{k_{i}}{\beta}+\frac{\left(1-s_{i}\right) \mu_{i}^{2}}{b}\right)
$$

with $i \in\{A, B\}$ and

$$
\mu_{i}=1-\lambda_{i}-\bar{\alpha}-\frac{t_{i}}{\beta} .
$$

Employing the symmetry assumption $k_{i}=1+n$ yields the equilibrium condition

$$
\varepsilon\left[(1+n)\left(1-\bar{\alpha}-\frac{t^{*}}{\beta}\right)+n \lambda^{*}\right]=(1+\varepsilon) t^{*}\left[\frac{1+n}{\beta}+\frac{1}{2 b}\left(1-\lambda^{*}-\bar{\alpha}-\frac{t^{*}}{\beta}\right)^{2}\right] .
$$

Analogously differentiating (11) with respect to $\lambda_{i}$ yields

$$
\frac{\partial u_{i}}{\partial \lambda_{i}}=-s_{i}\left(k_{i}-1-n_{i}\right) t_{i}+\varepsilon t_{i}\left(n_{i}-k_{i}\right)+(1+\varepsilon) \frac{\left(1-s_{i}\right) \mu_{i} t_{i}^{2}}{b}
$$

with $i \in\{A, B\}$. Symmetry yields the second equilibrium condition

$$
\frac{(1+\varepsilon) t^{*}}{2 b}\left(1-\lambda^{*}-\bar{\alpha}-\frac{t^{*}}{\beta}\right)-\varepsilon=0 .
$$

Equations (A.4) and (A.6) constitute a system of two equations in the two unknowns $t^{*}$ and $\lambda^{*}$. Solving this equation system yields (13) and (14) in the main text. 


\section{A.3. Partial tax coordination}

We totally differentiate (A.2) and use $\mathrm{d} k_{i}=0$, since $\mathrm{d} \lambda_{i}=\mathrm{d} \lambda_{j}=\mathrm{d} \lambda$ from the coordinated change in the thin capitalization rules and $\mathrm{d} t_{i}=\mathrm{d} t_{j}$ follows from symmetry. This yields in a first step

$$
\left[-\varepsilon+\frac{(1+\varepsilon) t^{*} \mu^{*}}{b}\right] \mathrm{d} \lambda=\left[\frac{(1+2 \varepsilon)(1+n)}{\beta}+\frac{(1+\varepsilon) \mu^{*}\left(\beta \mu^{*}-2 t^{*}\right)}{2 b \beta}\right] \mathrm{d} t_{i}
$$

where $\mu^{*}=1-\lambda^{*}-\bar{\alpha}-t^{*} / \beta$. Substituting the values for $t^{*}$ and $\lambda^{*}$ in the intial equilibrium [eqs. (13) and (14)] yields eqs. (19) and (20) in the main text.

\section{A.4. Asymmetric tax competition}

Totally differentiating (8), (A.2) and (A.5) and evaluating the resulting expressions at the symmetric equilibrium yields

$$
\begin{gathered}
\gamma_{1} \mathrm{~d} t_{i}+\gamma_{2} \mathrm{~d} \lambda_{i}+\gamma_{3} \mathrm{~d} k_{i}+\gamma_{4} \mathrm{~d} n_{i}+\gamma_{5} \mathrm{~d} s_{i}=0, \\
\gamma_{6} \mathrm{~d} t_{i}+\gamma_{7} \mathrm{~d} \lambda_{i}-\gamma_{8} \mathrm{~d} k_{i}+\gamma_{8} \mathrm{~d} n_{i}+\gamma_{9} \mathrm{~d} s_{i}=0, \\
\mathrm{~d} k_{i}=\frac{\mathrm{d} n_{i}+\mathrm{d} n_{j}}{2}+\gamma_{10}\left(\mathrm{~d} t_{j}-\mathrm{d} t_{i}\right)+\gamma_{11}\left(\mathrm{~d} \lambda_{j}-\mathrm{d} \lambda_{i}\right),
\end{gathered}
$$

with $i, j \in\{A, B\}, i \neq j$ and

$$
\begin{gathered}
\gamma_{1}=-\frac{\beta n^{2}(1+\varepsilon)(1-\bar{\alpha})^{2}(1+n+2 \varepsilon n)+2 b(1+n+\varepsilon+2 \varepsilon n)^{2}}{\beta^{2} n^{2}(1+\varepsilon)(1-\bar{\alpha})^{2}}, \quad \gamma_{2}=\varepsilon, \\
\gamma_{3}=\frac{b(1+n+\varepsilon+2 \varepsilon n)^{2}(1+2 \varepsilon)-\beta \varepsilon n^{2}(1+\varepsilon)^{2}(1-\bar{\alpha})^{2}}{\beta n(1+\varepsilon)(1-\bar{\alpha})(1+n+\varepsilon+2 \varepsilon n)}, \\
\gamma_{4}=-\frac{b(1+n+\varepsilon+2 \varepsilon n)^{2}(1+2 \varepsilon)-\beta \varepsilon n(1+n)(1+\varepsilon)^{2}(1-\bar{\alpha})^{2}}{\beta n(1+\varepsilon)(1-\bar{\alpha})(1+n+\varepsilon+2 \varepsilon n)}, \\
\gamma_{5}=\frac{4 b \varepsilon(1+n+\varepsilon+2 \varepsilon n)}{\beta n(1+\varepsilon)(1-\bar{\alpha})}, \gamma_{6}=\frac{2 b(1+n+\varepsilon+2 \varepsilon n)^{2}-\beta \varepsilon n^{2}(1+\varepsilon)(1-\bar{\alpha})^{2}}{2 b \beta n(1-\bar{\alpha})(1+n+\varepsilon+2 \varepsilon n)}, \\
\gamma_{7}=-\frac{\beta \varepsilon n(1+\varepsilon)(1-\bar{\alpha})}{2 b(1+n+\varepsilon+2 \varepsilon n)}, \gamma_{8}=\frac{1+2 \varepsilon}{2}, \gamma_{9}=-2 \varepsilon, \gamma_{10}=\frac{1+n+\varepsilon+2 \varepsilon n}{\beta n(1+\varepsilon)(1-\bar{\alpha})}, \\
\gamma_{11}=-\frac{\beta \varepsilon n(1-\bar{\alpha})}{2 b(1+n+\varepsilon+2 \varepsilon n)}
\end{gathered}
$$

In computing (A.11) - (A.16) we used the equilibrium values (13) and (14). Next we derive (A.8) for country $j$, subtract the resulting expression from (A.8) and use (A.10) 
to replace $\mathrm{d} k_{i}$ and $\mathrm{d} k_{j}$. Proceeding in the same way with (A.9) yields

$$
\underbrace{\left(\begin{array}{cc}
\gamma_{1}-2 \gamma_{3} \gamma_{10} & \gamma_{2}-2 \gamma_{3} \gamma_{11} \\
\gamma_{6}+2 \gamma_{8} \gamma_{10} & \gamma_{7}+2 \gamma_{8} \gamma_{11}
\end{array}\right)}_{=: J}\left(\begin{array}{c}
\mathrm{d}\left(t_{i}-t_{j}\right) \\
\mathrm{d}\left(\lambda_{i}-\lambda_{j}\right)
\end{array}\right)=\left(\begin{array}{cc}
-\gamma_{4} & -\gamma_{5} \\
-\gamma_{8} & -\gamma_{9}
\end{array}\right)\left(\begin{array}{c}
\mathrm{d}\left(n_{i}-n_{j}\right) \\
\mathrm{d}\left(s_{i}-s_{j}\right)
\end{array}\right) .
$$

After some tedious computations, the determinant of the matrix $J$ can be written as

$$
|J|=\frac{\varepsilon n(1-\bar{\alpha})\left[b(2+3 \varepsilon)(1+n+\varepsilon+2 \varepsilon n)^{3}-\beta \varepsilon^{2} n^{2}(1+\varepsilon)^{2}(1-\bar{\alpha})^{2}\right]}{2 b^{2}(1+n+\varepsilon+2 \varepsilon n)^{3}} .
$$

Stability of the Nash equilibrium implies $|J|>0 .{ }^{17}$

To derive (22) and (23) in the text, we set $\mathrm{d} s_{i}=-\mathrm{d} s_{j}$ in (A.17). Applying Cramer's rule then immediately gives (22) and (23). To show (24), set $\mathrm{d} n_{j}=0$ in (A.17). Cramer's rule then yields

$$
\begin{gathered}
\frac{\mathrm{d}\left(t_{i}-t_{j}\right)}{\mathrm{d} n_{i}}=\frac{\beta \varepsilon^{2} n(1+\varepsilon)(1-\bar{\alpha})^{2}[2+n+\varepsilon(3+n)]}{2 b(1+n+\varepsilon+2 \varepsilon n)^{2}|J|} \\
\frac{\mathrm{d}\left(\lambda_{i}-\lambda_{j}\right)}{\mathrm{d} n_{i}}=\frac{(1+n+\varepsilon+2 \varepsilon n)^{2}\left[2 \varepsilon(2+3 \varepsilon)+n(1+\varepsilon)(1+4 \varepsilon)+(n+2 \varepsilon n)^{2}\right]}{2 \beta n(1+n+\varepsilon+2 \varepsilon n)^{2}|J|} \\
-\frac{\varepsilon^{2} n(1+n)(1+\varepsilon)^{2}(1-\bar{\alpha})^{2}}{2 b(1+n+\varepsilon+2 \varepsilon n)^{2}|J|} .
\end{gathered}
$$

From these expressions, along with (3) and (5), we can compute the effect on $\tau_{i}^{n}-\tau_{j}^{n}$ and $\tau_{i}^{m}-\tau_{j}^{m}$. After several manipulations we obtain

$$
\begin{gathered}
\frac{\mathrm{d}\left(\tau_{i}^{n}-\tau_{j}^{n}\right)}{\mathrm{d} n_{i}}=\frac{b \beta \varepsilon(1+\varepsilon)(1-\bar{\alpha})^{2}(1+n+\varepsilon)(2+n+\varepsilon(3+n))}{b(2+3 \varepsilon)(1+n+\varepsilon+2 \varepsilon n)^{3}-\beta \varepsilon^{2} n^{2}(1+\varepsilon)^{2}(1-\bar{\alpha})^{2}}>0, \\
\frac{\mathrm{d}\left(\tau_{i}^{m}-\tau_{j}^{m}\right)}{\mathrm{d} n_{i}}=-\frac{\left.b(1+2 \varepsilon)\left[\beta \varepsilon^{2} n(1+\varepsilon)(1-\bar{\alpha})^{2}+b(1+n+\varepsilon+2 \varepsilon n)^{3}\right]\right)}{b(2+3 \varepsilon)(1+n+\varepsilon+2 \varepsilon n)^{3}-\beta \varepsilon^{2} n^{2}(1+\varepsilon)^{2}(1-\bar{\alpha})^{2}}<0,
\end{gathered}
$$

where the signs of (A.19) and (A.20) follow from the stability condition $|J|>0$. This proves (24) in the text.

\footnotetext{
${ }^{17}$ Stability requires that the Jacobian determinant of the system of equations consisting of (A.2) and (A.5) for $i \in\{A, B\}$, evaluated at the symmetric Nash equilibrium, has to be negative semidefinite. It can be shown that this stability condition implies $|J|>0$. Details can be obtained upon request.
} 


\section{References}

Altshuler, R. and H. Grubert (2006). Governments and multinational corporations in the race to the bottom. Tax Notes International 41(5), 459-474.

Auerbach, A. (2002). Taxation and corporate financial policy. In: A.J. Auerbach and M. Feldstein (eds.), Handbook of Public Economics, Vol. 3, 1251-1292.

Bucovetsky, S. (1991), Asymmetric tax competition. Journal of Urban Economics 30, 167-181.

Bucovetsky, S. and A. Haufler (2008). Tax competition when firms choose their organizational form: Should tax loopholes for multinationals be closed? Journal of International Economics 74, 188-201.

Buettner, T., M. Overesch, U. Schreiber and G. Wamser (2006). Taxation and capital structure choice - evidence from a panel of German multinationals. CESifo Working Paper No. 1841, Munich.

Buettner, T., M. Overesch, U. Schreiber and G. Wamser (2008). The impact of thin capitalization rules on multinationals' financing and investment decisions. Deutsche Bundesbank Discussion Paper No. 03/2008., Frankfurt.

Desai, M., F. Foley and J. Hines (2004). A multinational perspective on capital structure choice and internal capital markets. Journal of Finance 59, 2451-2487.

Dourado, A. and R. de la Feria (2008). Thin capitalization rules in the context of the CCCTB. Oxford University Centre for Business Taxation, Working Paper 08/04.

Egger, P., W. Eggert and H. Winner (2007). Saving taxes through foreign plant ownership. CESifo Working Paper No. 1887, Munich.

European Commission (2007). The application of anti-abuse measures in the area of direct taxation - within the EU and in relation to third countries. Document COM (2007) 785. Brussels, 10 December 2007.

European Commission (2008). Anti-abuse rules. Common Consolidated Corporate Tax Base Working Group, Working Paper CCCTB/WP065. Brussels, 26 March 2008. 
Fuest, C. (2008). The European Commission's proposal for a Common Consolidated Corporate Tax Base. Paper presented at the conference 'Business Taxation in a Globalized World', Centre for Business Taxation, Oxford, June 16, 2008.

Fuest, C. and T. Hemmelgarn (2005). Corporate tax policy, foreign firm ownership and thin capitalization. Regional Science and Urban Economics 35, 508-526.

Gordon, R.H. and Y. Lee (2001). Do taxes affect corporate debt policy? Evidence from U.S. corporate tax return data. Journal of Public Economics 82, 195-224.

Gouthière, B. (2005). A comparative study of the thin capitalization rules in the member states of the European Union and certain other countries. European Taxation 45, 367-451.

Grubert, H. (2003), Intangible income, intercompany transactions, income shifting, and the choice of location. National Tax Journal 56, 221-242.

Haufler, A. and G. Schjelderup (2000). Corporate tax systems and cross country profit shifting. Oxford Economic Papers 52, 306-325.

Haupt, A. and W. Peters (2005). Restricting preferential tax regimes to avoid harmful tax competition. Regional Science and Urban Economics 35, 493-507.

Hines, J.R. (2007). Corporate taxation and international competition. In: A.J. Auerbach, J.R. Hines and J. Slemrod (eds.), Taxing corporate income in the 21st century. Cambridge University Press, 268-306.

Hong, Q. and M. Smart (2007). In praise of tax havens: International tax planning and foreign direct investment. CESifo Working Paper No. 1942. Munich.

Huizinga, H., L. Laeven and G. Nicodème (2008). Capital structure and international debt-shifting. Journal of Financial Economics 88, 80-118.

Janeba, E. and W. Peters (1999). Tax evasion, tax competition and the gains from nondiscrimination: The case of interest taxation in Europe. The Economic Journal 109, 93-101.

Janeba, E. and M. Smart (2003). Is targeted tax competition less harmful than its remedies? International Tax and Public Finance 10, 259-280. 
Keen, M. (2001). Preferential regimes can make tax competition less harmful. National Tax Journal 54, 757-762.

Mintz, J. (2004). Conduit entities: Implications of indirect tax-efficient financing structures for real investment. International Tax and Public Finance 11, 419-434.

Mintz, J. and M. Smart (2004). Income shifting, investment, and tax competition: theory and evidence from provincial taxation in Canada. Journal of Public Economics 88, 1149-1168.

Mintz, J. and A. Weichenrieder (2005). Taxation and the financial structure of German outbound FDI. CESifo Working Paper 1612, Munich.

Myers, S.C. (2001). Capital Structure. Journal of Economic Perspectives 15, 81-102.

OECD (2007). Tax effects on foreign direct investment. Recent evidence and policy analysis. OECD Tax Policy Studies, No. 17. Paris.

Peralta, S., X. Wauthy and T. van Ypersele (2006). Should countries control international profit shifting? Journal of International Economics 68, 24-37.

Schindler, D. and G. Schjelderup (2008). Multinationals, minority ownership and tax-efficient financing structures. Mimeo. University of Konstanz and Norwegian School of Economics and Business Administration.

Slemrod, J.B. and J.D. Wilson (2006), Tax competition and parasitic tax havens. NBER Working Paper No. W12225.

Tanzi, V. (1995). Taxation in an integrating world. The Brookings Institution, Washington, D.C.

Weichenrieder, A. and H. Windischbauer (2008). Thin-capitalization rules and company responses. Paper presented at the Second Summer Symposium of the Centre for Business Taxation, Oxford, June 17-20, 2008.

Wilson, J.D. (1991), Tax competition with interregional differences in factor endowments. Regional Science and Urban Economics 21, 423-451. 


\section{CESifo Working Paper Series}

for full list see www.cesifo-group.org/wp

(address: Poschingerstr. 5, 81679 Munich, Germany, office@cesifo.de)

2365 Stefan Voigt, The (Economic) Effects of Lay Participation in Courts - A Cross-Country Analysis, August 2008

2366 Tobias König and Andreas Wagener, (Post-)Materialist Attitudes and the Mix of Capital and Labour Taxation, August 2008

2367 Ximing Wu, Andreas Savvides and Thanasis Stengos, The Global Joint Distribution of Income and Health, August 2008

2368 Alejandro Donado and Klaus Wälde, Trade Unions Go Global!, August 2008

2369 Hans Gersbach and Hans Haller, Exit and Power in General Equilibrium, August 2008

2370 Jan P.A.M. Jacobs and Jan-Egbert Sturm, The Information Content of KOF Indicators on Swiss Current Account Data Revisions, August 2008

2371 Oliver Hülsewig, Johannes Mayr and Timo Wollmershäuser, Forecasting Euro Area Real GDP: Optimal Pooling of Information, August 2008

2372 Tigran Poghosyan and Jakob de Haan, Determinants of Cross-Border Bank Acquisitions in Transition Economies: A Latent Class Analysis, August 2008

2373 David Anthoff and Richard S.J. Tol, On International Equity Weights and National Decision Making on Climate Change, August 2008

2374 Florian Englmaier and Arno Schmöller, Reserve Price Formation in Online Auctions, August 2008

2375 Karl Farmer, Birgit Friedl and Andreas Rainer, Effects of Unilateral Climate Policy on Terms of Trade, Capital Accumulation, and Welfare in a World Economy, August 2008

2376 Monika Bütler, Stefan Staubli and Maria Grazia Zito, The Role of the Annuity's Value on the Decision (Not) to Annuitize: Evidence from a Large Policy Change, August 2008

2377 Inmaculada Martínez-Zarzoso, The Impact of Urbanization on $\mathrm{CO}_{2}$ Emissions: Evidence from Developing Countries, August 2008

2378 Brian Roberson and Dmitriy Kvasov, The Non-Constant-Sum Colonel Blotto Game, August 2008

2379 Ian Dew-Becker, How Much Sunlight Does it Take to Disinfect a Boardroom? A Short History of Executive Compensation Regulation, August 2008

2380 Cécile Aubert, Oliver Falck and Stephan Heblich, Subsidizing National Champions: An Evolutionary Perspective, August 2008 
2381 Sebastian Buhai, Miguel Portela, Coen Teulings and Aico van Vuuren, Returns to Tenure or Seniority?, August 2008

2382 Erkki Koskela and Jan König, Flexible Outsourcing, Profit Sharing and Equilibrium Unemployment, August 2008

2383 Torberg Falch and Justina AV Fischer, Does a Generous Welfare State Crowd out Student Achievement? Panel Data Evidence from International Student Tests, September 2008

2384 Pedro Gomes and François Pouget, Corporate Tax Competition and the Decline of Public Investment, September 2008

2385 Marko Koethenbuerger, How Do Local Governments Decide on Public Policy in Fiscal Federalism? Tax vs. Expenditure Optimization, September 2008

2386 Ronald McKinnon and Gunther Schnabl, China's Exchange Rate Impasse and the Weak U.S. Dollar, September 2008

2387 Yan-Leung Cheung, Yin-Wong Cheung and Alan T.K. Wan, A High-Low Model of Daily Stock Price Ranges, September 2008

2388 Louis Eeckhoudt and Harris Schlesinger, Changes in Risk and the Demand for Saving, September 2008

2389 Carsten Hefeker and Blandine Zimmer, Uncertainty and Fiscal Policy in an Asymmetric Monetary Union, September 2008

2390 Jay Pil Choi and Byung-Cheol Kim, Net Neutrality and Investment Incentives, September 2008

2391 Marcel Gérard, Financing Bologna, the Internationally Mobile Students in European Higher Education, September 2008

2392 Annette Alstadsæter and Knut Reidar Wangen, Corporations' Choice of Tax Regime when Transition Costs are Small and Income Shifting Potential is Large, September 2008

2393 António Afonso and Christophe Rault, 3-Step Analysis of Public Finances Sustainability: the Case of the European Union, September 2008

2394 Betsey Stevenson and Justin Wolfers, Economic Growth and Subjective Well-Being: Reassessing the Easterlin Paradox, September 2008

2395 Bernhard Eckwert and Itzhak Zilcha, Private Investment in Higher Education: Comparing Alternative Funding Schemes, September 2008

2396 Øystein Foros, Hans Jarle Kind and Jan Yngve Sand, Slotting Allowances and Manufacturers' Retail Sales Effort, September 2008 
2397 Mohammad Reza Farzanegan, Illegal Trade in the Iranian Economy: Evidence from a Structural Model, September 2008

2398 Olivier Bos, Charity Auctions for the Happy Few, September 2008

2399 Robert S. Chirinko and Debdulal Mallick, The Marginal Product of Capital: A Persistent International Puzzle, September 2008

2400 Ben D'Exelle and Arno Riedl, Elite Capture, Political Voice and Exclusion from Aid: An Experimental Study, September 2008

2401 Torben M. Andersen and Joydeep Bhattacharya, On Myopia as Rationale for Social Security, September 2008

2402 Fabienne Llense, French CEO Compensations: What is the Cost of a Mandatory Upper Limit?, September 2008

2403 Valentina Bosetti, Carlo Carraro, Alessandra Sgobbi and Massimo Tavoni, Delayed Action and Uncertain Targets. How Much Will Climate Policy Cost?, September 2008

2404 Robert G. Chambers, Rolf Färe, Shawna Grosskopf and Michael Vardanyan, Generalized Quadratic Revenue Functions, September 2008

2405 Leonidas Enrique de la Rosa, Overconfidence in a Career-Concerns Setting, September 2008

2406 Marcus Drometer and Johannes Rincke, The Design of Political Institutions: Electoral Competition and the Choice of Ballot Access Restrictions in the United States, September 2008

2407 Markku Lanne and Helmut Lütkepohl, Stock Prices and Economic Fluctuations: A Markov Switching Structural Vector Autoregressive Analysis, September 2008

2408 Thomas L. Brewer, International Energy Technology Transfers for Climate Change Mitigations, September 2008

2409 Alexander Kemnitz, Native Welfare Losses from High Skilled Immigration, September 2008

2410 Xavier Vives, Strategic Supply Function Competition with Private Information, September 2008

2411 Fabio Padovano and Roberto Ricciuti, The Political Competition-Economic Performance Puzzle: Evidence from the OECD Countries and the Italian Regions, September 2008

2412 Joan Costa-Font and Mireia Jofre-Bonet, Body Image and Food Disorders: Evidence from a Sample of European Women, September 2008

2413 Thorsten Upmann, Labour Unions - To Unite or to Separate?, October 2008 
2414 Sascha O. Becker and Ludger Woessmann, Luther and the Girls: Religious Denomination and the Female Education Gap in $19^{\text {th }}$ Century Prussia, October 2008

2415 Florian Englmaier and Stephen Leider, Contractual and Organizational Structure with Reciprocal Agents, October 2008

2416 Vittorio Daniele and Ugo Marani, Organized Crime and Foreign Direct Investment: The Italian Case, October 2008

2417 Valentina Bosetti, Carlo Carraro, Alessandra Sgobbi and Massimo Tavoni, Modelling Economic Impacts of Alternative International Climate Policy Architectures. A Quantitative and Comparative Assessment of Architectures for Agreement, October 2008

2418 Paul De Grauwe, Animal Spirits and Monetary Policy, October 2008

2419 Guglielmo Maria Caporale, Christophe Rault, Robert Sova and Anamaria Sova, On the Bilateral Trade Effects of Free Trade Agreements between the EU-15 and the CEEC-4 Countries, October 2008

2420 Yin-Wong Cheung and Daniel Friedman, Speculative Attacks: A Laboratory Study in Continuous Time, October 2008

2421 Kamila Fialová and Ondřej Schneider, Labour Market Institutions and their Effect on Labour Market Performance in the New EU Member Countries, October 2008

2422 Alexander Ludwig and Michael Reiter, Sharing Demographic Risk - Who is Afraid of the Baby Bust?, October 2008

2423 Doina Maria Radulescu and Michael Stimmelmayr, The Welfare Loss from Differential Taxation of Sectors in Germany, October 2008

2424 Nikolaus Wolf, Was Germany ever United? Evidence from Intra- and International Trade 1885 - 1933, October 2008

2425 Bruno S. Frey, David A. Savage and Benno Torgler, Noblesse Oblige? Determinants of Survival in a Life and Death Situation, October 2008

2426 Giovanni Facchini, Peri Silva and Gerald Willmann, The Customs Union Issue: Why do we Observe so few of them?, October 2008

2427 Wido Geis, Silke Uebelmesser and Martin Werding, Why go to France or Germany, if you could as well go to the UK or the US? Selective Features of Immigration to four major OECD Countries, October 2008

2428 Geeta Kingdon and Francis Teal, Teacher Unions, Teacher Pay and Student Performance in India: A Pupil Fixed Effects Approach, October 2008

2429 Andreas Haufler and Marco Runkel, Firms' Financial Choices and Thin Capitalization Rules under Corporate Tax Competition, October 2008 